\title{
Statistical Analysis of Seasonal Rainfall Variability and Characteristics in Ahmednagar District of Maharashtra, India
}

\author{
*Gadekar Deepak Janardhan, Soniya Sonkar** \\ * Assistant Professor at Padmashri Vikhe Patil College of Arts Science \& Commerce, Pravaranagar \\ Maharashtra, India. Department of Geography UG and PG, Affiliated Savitribai Phule Pune University \\ Pune, .Tal -Rahata Dist- Ahmednagar, , Maharashtra, India \\ ** Department of Geography, Institute of Science, Banaras Hindu University, Varanasi, India
}

\begin{abstract}
Article Info

Volume 7, Issue 5

Page Number: 125-136

Publication Issue :

September-October-2020

\section{Article History}

Accepted : 18 Sep 2020

Published : 25 Sep 2020

\section{INTRODUCTION}

As India is an agricultural country, Indian agricultural is totally dependent on monsoon rainfall. But Indian monsoon rainfall in India is uneven and unregularly due to this there is a large amount of drought in India. Ahmednagar district falls in the rain fed region as the entire winds are blocked in the Sahyadri rage and rest of the dry winds move to the rest other area. There are a total of tehsil in study area but the 13 tehsil are drought prone. There for the period of 1981 to 2014 has been studied in Ahmednagar district to study the
\end{abstract}

The three major characteristics of rainfall are mainly its amount, frequency and intensity. The value of rainfall varies greatly from day to day, place to place, month and year to year. Generally Akole tehsil receives the highest rainfall and Karjat and Jamkhed tehsils receives the least rainfall. The main reason for the highest rainfall in Akole tehsil is orographic type rainfall. The rainfall characteristics and distribution in drought prone area in study area. The research covers rainfall data from 1981 to 2014 and the rainfall data is taken from the statistical department website of Ahmednagar district.

Keywords : Drought Prone area, Watershed Management, Rainfall Characteristics, Rainfall Distribution distributions and characteristics of rainfall. Water is the most importance natural resources as well as water is used by human for variety of purposes therefor, the development of a region depends on water for economic development, social, cultural and political etc[2,14,21]. The development of agricultural and agricultural in any area depend on water just as the growth of plants depends on distribution of plants $[23,24]$. Topography is the most importance factor affecting the distributions of rainfall $[4,5,16$,$] .$ Environment is powerful tool for determination, interpretation and analysis of spatial information

Copyright: (C) the author(s), publisher and licensee Technoscience Academy. This is an open-access article distributed under the terms of the Creative Commons Attribution Non-Commercial License, which permits unrestricted noncommercial use, distribution, and reproduction in any medium, provided the original work is properly cited 
related to river basins $[17,18,19]$. Proper use of water and its good for this there planning of water reduce drought prone condition. For this there is a need to create awareness among the peoples and proper use and solution of various technology. Water is one of the elements that contribution to the economic development of any part and any area [11,12]. The level of development of any part is affected by many factors but water is the most importance factors $[8,13]$.

\section{METHODS AND MATERIAL}

\section{STUDY AREA:}

The present study Ahmednagar district has been selected as a study area. It extends between $18^{\circ} 20^{\prime}$ and $19^{\circ} 59^{\prime}$ north latitudes and $73^{\circ} 40^{\prime}$ to $75^{\circ} 43^{\prime}$ east longitudes (Map.1) located in part in the upper Godavari basin. The district is very dense in shape and length of $200 \mathrm{~km}$. a width of $210 \mathrm{~km}$. This study region is divided into there are three physical divisions namely, first Sahyadri moutons ranges i.e. Kalsubai, Adula, Baleshwar and Harishchandragad, second Plateau third plains area. The Godavari, Bhima River is the main rivers in this district with the major tributaries are Paravara, Mula, Sina, Dhora, Kukdi etc. Ahmednagar district occupies 17,048 square $\mathrm{km}$ geographical area the administratively there are divided into 14 tehsils. The average annual rainfalls is $578.8 \mathrm{~mm}$. (22.79") and mean daily maximum temperatures is $39^{\circ} \mathrm{C}$ and mean daily minimum temperature is $11.7^{\circ} \mathrm{C}$. In study region 71.10 percent area under cultivation area out of them 32.40 percent is irrigated and 67.60 percent rain fed or rain shadow area. According to 2011 census population is 45, 43,083 in which male and female are 2,348,802 and
2,194,281 correspondingly and density of population was 266 persons per square kilometers.

\section{AMIS AND OBJECTIVE:}

The main purpose of this research is Rainfall Characteristics and Distribution of Drought Prone Area in Ahmednagar District. Since then, the research has been conducted with various objectives, mainly in the spatio-temporal analysis of rainfall in the study area. The research period of this study is from period of 1981 to 2014 years.

\section{DATA SOURCE AND METHODOLOGY:}

The present research article have secondary data use for Ahmednagar statistical department. The data analyzed and presented in the form of table and maps with analysis is done with the help of SPSS software and for mapping purposes used Arc GIS10.3 version GIS software. In this research she has drawn maps according to the difference between 1981, 1992, 2003 and 2014 the index value are namely divided into three groups high rainfall area above $650 \mathrm{~mm}$, moderate rainfall area $575-650 \mathrm{~mm}$ and low rainfall area below $575 \mathrm{~mm}$. in addition maps have been drawn in the positive and negative form for the years 1981 to 2014. Also line graph of average rainfall for the period rainfall 1981 to 2014 has been drawn.

\section{RESULTS AND DISCUSSION}

The Ahmednagar district is drought prone area of Maharashtra state. There for Ahmednagra district have facing problem of agricultural development within the economic. The Ahmednagar district is divided in two major zone in first Northern and southern Ahmednagar. The southern parts have major problem is water it is spite of canal irrigation facilities in the district the rural areas are facing problem of 
scarcity of water and maximum number of villages have been tanker-affected. The drought prone zone in the state is not in position to achieve the agricultural growth, obviously due to scarcity of water $[7,28,29$, 30]. Even the irrigated areas are facing the problem of retarding the growth of agriculture in the study area. Majority of the villages in the south Ahmednagar are facing problem of drinking water. This is main environmental issue observed due to over utilization of water resources for agriculture and for various other purposes.

\section{Average Rainfall:}

The rainfall is vital role for growth of vegetation and effect of forest density [7, 22]. Also rainfall influence on agricultural pattern and development $[9,25,26]$ therefore need of study of rainfall distribution. Graph number one show the average rainfall in Ahmednagar district during periods is from 1981 to 2014 . There is a large amount of various moment in this periods in which no such constant rainfall has fallen. The highest rainfall was seen in 1998 and 2010 and at the same time the lowest rainfall fell in 2003 and 2014 it was lower than the average appears to have fallen short.

\section{Graph no 01: Average Rainfall (Rainfall in CM)}

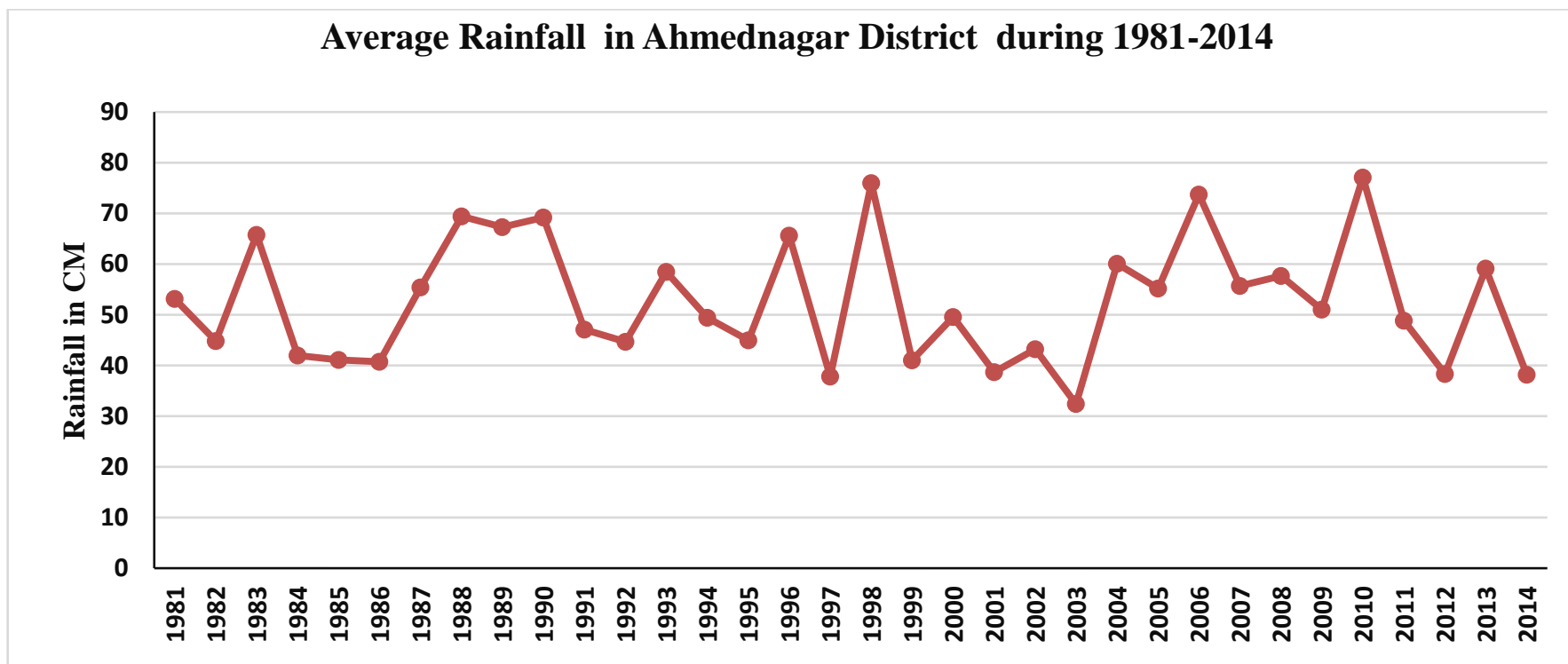

Graph number two shows the average rainfall in the entire tehsil of study area period in 1981 to 2014. The lowest rainfall falls in the (Less than $450 \mathrm{~mm}$ ) tehsil Shrigonda, Shevgaon, Karjat, Jamkhed, Pathardi and Nagar and moderated rainfall $(450-550 \mathrm{~mm})$ Rahata, Rahuri, Shrirampur, Kopergaon, , Parner as well as highest rainfall fall in more than $650 \mathrm{~mm}$ is akole tehsil. The most importance feature in the total rainfall over a periods of 36 years is that Karjat, Jamkhed, Shrigonda, Shevgaon, Pathardi and Nevasa tehsils is drought prone area is the exporter with the lowest rainfall. Here all the other information shown in Graph number two. 
Graph no 02: Average Rainfall in Tehsil wise

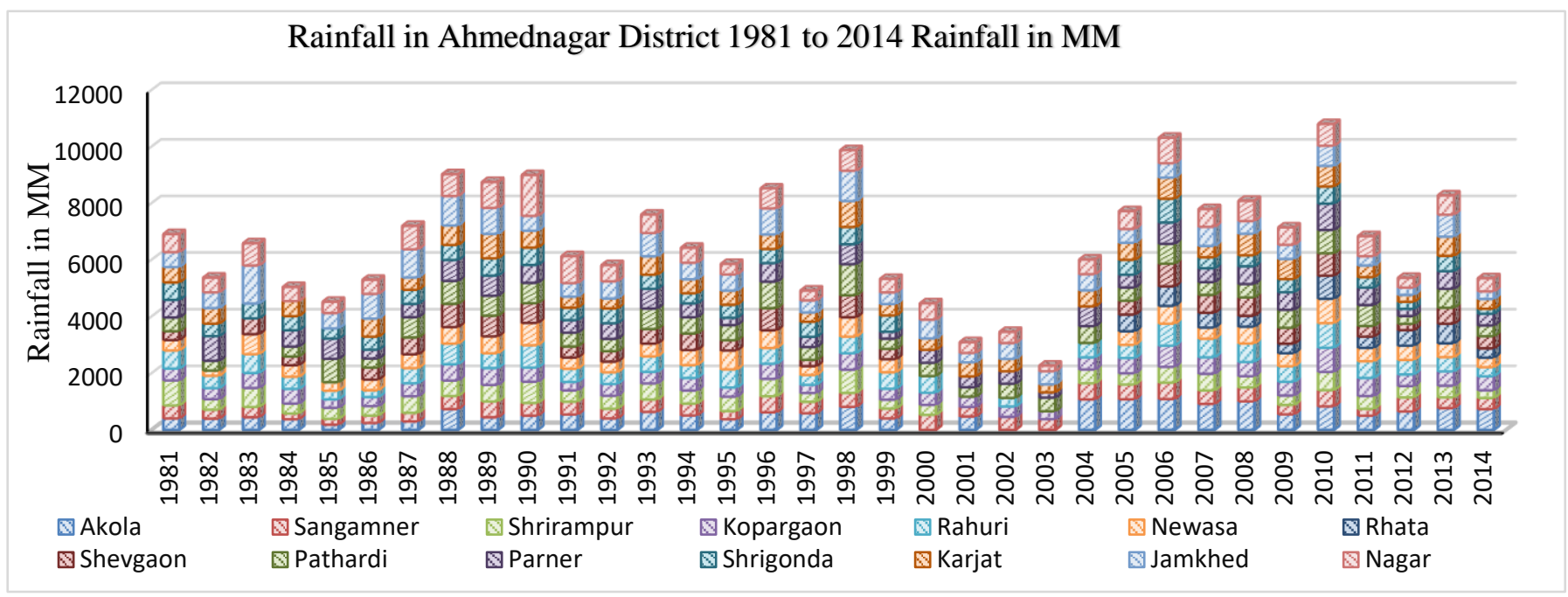

Rainfall Distribution (1981 to 2014):

Map no 02 shows the distribution of rainfall in the 1981 periods and there are three rainfall zone or tehsil have mainly high more than $(650 \mathrm{~mm})$, moderate $(575-650 \mathrm{~mm})$ and low (less than $575 \mathrm{~mm})$ rainfall. The highest rainfall in this periods in Shrirampur $(880 \mathrm{~mm})$ tehsil and followed by moderated rainfall tehsil are Rahuri $(639 \mathrm{~mm})$, Parner $(622 \mathrm{~mm})$, Shrigonda $(614 \mathrm{~mm})$, Nagar $(639 \mathrm{~mm})$. and the lowest rainfall tehsils are Akola (404mm), Sangamner (459mm), Kopargaon (420mm), Newasa (366mm) ,Shevgaon (314mm), Pathardi (483mm), Karjat (542mm),Jamkhed (527mm)

Table No 1: Rainfall distribution in 1981

\begin{tabular}{|l|l|c|l|}
\hline Index & Index value & $\begin{array}{l}\text { Number of } \\
\text { Tehsils }\end{array}$ & Name of the Tehsil \\
\hline High Rainfall & Above $650 \mathrm{~mm}$. & 01 & Shrirampur \\
\hline $\begin{array}{l}\text { Moderate } \\
\text { Rainfall }\end{array}$ & $575-650 \mathrm{~mm}$. & 04 & Rahuri, Parner, Shrigonda, Nagar. \\
\hline Low Rainfall & Below $575 \mathrm{~mm}$. & 08 & $\begin{array}{l}\text { Akola,Sangamner,Kopargaon,Newasa Rahata } \\
\text {,Shevgaon, Pathardi ,Karjat,Jamkhed }\end{array}$ \\
\hline
\end{tabular}

Map no 03 show the distribution of rain fall of 1992 but no high rainfall has fail in any tehsil this year but in the moderated rainfall zone this year only one tehsil has received above average rainfall in Jamkhed tehsil $(603 \mathrm{~mm})$. The lowest rainfall falls this year as a total of 12 tehsils in the low rainfall zone this year, those tehsil are Shrirampur $(456 \mathrm{~mm})$ Rahuri $(407 \mathrm{~mm})$, Parner $(551 \mathrm{~mm})$, Shrigonda (522mm), Nagar(572mm). Akola $(405 \mathrm{~mm})$, Sangamner $(456 \mathrm{~mm})$,Kopargaon $(418 \mathrm{~mm})$, Newasa $(380 \mathrm{~mm})$, Shevgaon $(369 \mathrm{~mm})$, Pathardi (435mm), Karjat(352mm). 
Table No 2: Rainfall distribution in 1992

\begin{tabular}{|l|l|l|l|}
\hline Index & Index value & $\begin{array}{l}\text { Number of } \\
\text { Tehsils }\end{array}$ & Name of the Tehsil \\
\hline High Rainfall & Above $650 \mathrm{~mm}$. & 00 & Nil \\
\hline $\begin{array}{l}\text { Moderate } \\
\text { Rainfall }\end{array}$ & $575-650 \mathrm{~mm}$. & 01 & Jamkhed \\
\hline Low Rainfall & Below $575 \mathrm{~mm}$. & 12 & $\begin{array}{l}\text { Shrirampur Rahuri, Parner, Shrigonda, Nagar. } \\
\text { Akola,Sangamner,Kopargaon,Newasa,Shevgaon , } \\
\text { Pathardi ,Karjat. }\end{array}$ \\
\hline
\end{tabular}

The map number four shows the distribution of rainfall in 2003, during tis periods no tehsil in high and moderated has received this types of rainfall. This means that there was a severe drought in the year. This year low rainfall has also fallen in 14 tehsils, Jamkhed(460mm), Shrirampur (313mm) Rahuri (299mm), Parner(190mm), Shrigonda(87mm), Nagar(199), Akola(489) ,Sangamner (380mm),Kopargaon(280mm),Newasa (219mm),Shevgaon (320), Pathardi (476mm),Karjat (281mm), Rahata (249mm).

Table No 3: Rainfall distribution in 2003

\begin{tabular}{|l|l|c|l|}
\hline Index & Index value & Number of Tehsils & Name of the Tehsil \\
\hline High Rainfall & Above $650 \mathrm{~mm}$. & 00 & Nil \\
\hline Moderate Rainfall & $575-650 \mathrm{~mm}$. & 00 & Nil \\
\hline Low Rainfall & Below $575 \mathrm{~mm}$. & 14 & $\begin{array}{l}\text { Jamkhed, Shrirampur Rahuri, } \\
\text { Parner, Shrigonda, Nagar, Akola } \\
\text {,Sangamner ,Kopargaon,Newasa } \\
\text {,Shevgaon, Pathardi ,Karjat, Rahata. }\end{array}$ \\
\hline
\end{tabular}

Map number shows the 2014 rainfall distribution. There is only one tehsil in high rainfall this year is Akole $(733 \mathrm{~mm})$, but no tehsils included in the moderated group in this year. But in the remaining 13 tehsils the rain fall is below average grouped those tehsils area Jamkhed $(268 \mathrm{~mm}), \quad$ Shrirampur $\quad(273 \mathrm{~mm})$ Rahuri(322mm), Parner(414mm), Shrigonda (176mm), Nagar $\quad(465 \mathrm{~mm})$,Sangamner (392mm),Kopargaon(491mm),Newasa $(337 \mathrm{~mm})$, Shevgaon $(429 \mathrm{~mm})$, Pathardi $(379 \mathrm{~mm})$, Karjat $(344 \mathrm{~mm})$, Rahata(328mm).

Table No 4: Rainfall distribution in 2014

\begin{tabular}{|l|l|l|l|}
\hline Index & Index value & $\begin{array}{l}\text { Number of } \\
\text { Tehsils }\end{array}$ & Name of the Tehsil \\
\hline High Rainfall & Above $650 \mathrm{~mm}$. & 01 & Akole \\
\hline Moderate Rainfall & $575-650 \mathrm{~mm}$. & Nil & Nil \\
\hline Low Rainfall & Below $575 \mathrm{~mm}$. & 13 & $\begin{array}{l}\text { Jamkhed, Shrirampur Rahuri, Parner, } \\
\text { Shrigonda, Nagar, } \\
\text {,Sangamner,Kopargaon,Newasa } \\
\text {,Shevgaon, Pathardi ,Karjat, Rahata. }\end{array}$ \\
\hline
\end{tabular}


The map no. 06 shows the changes rainfall during in 1981 to 2014 this difference is for a total of 33 years. It mainly shows positive and negative changes 181to 2014. In theses 33 years there has been a positive changes in three tehsil namely Akole $(329 \mathrm{~mm})$, Kopargaon $(71 \mathrm{~mm})$, Shevgaon $(115 \mathrm{~mm})$. During this periods negative rainfall is seen in the remaining ten tehsils namely Jamkhed (- $259 \mathrm{~mm})$, Shrirampur $(-607 \mathrm{~mm})$, Rahuri($317 \mathrm{~mm})$, Parner $(-208 \mathrm{~mm})$, Shrigonda $(-438 \mathrm{~mm})$, Nagar $(-174 \mathrm{~mm})$, Sangamner $(-67 \mathrm{~mm})$, Newasa(-29mm) , Pathardi $(-104 \mathrm{~mm})$,Karjat $(-198 \mathrm{~mm})$, Newasa $(-29 \mathrm{~mm})$ but it does not show Rahata Tehsil because of Rahata Tehsil was created in 2001, so does not show all detail show in Map no 6and Table no.5.

Table No 5: Change of Rainfall (1981 to 2014)

\begin{tabular}{|l|l|l|}
\hline Index & Number of Tehsil & Name of the Tehsil \\
\hline Positive change & $\mathbf{0 3}$ & Akole, Kopargaon,Shevgaon \\
\hline Negative change & 10 & $\begin{array}{l}\text { Jamkhed, Shrirampur Rahuri, Parner, Shrigonda, } \\
\text { Nagar, ,Sangamner, Newasa ,Shevgaon, Pathardi } \\
\text {,Karjat. }\end{array}$ \\
\hline
\end{tabular}

Map no 01: Location map

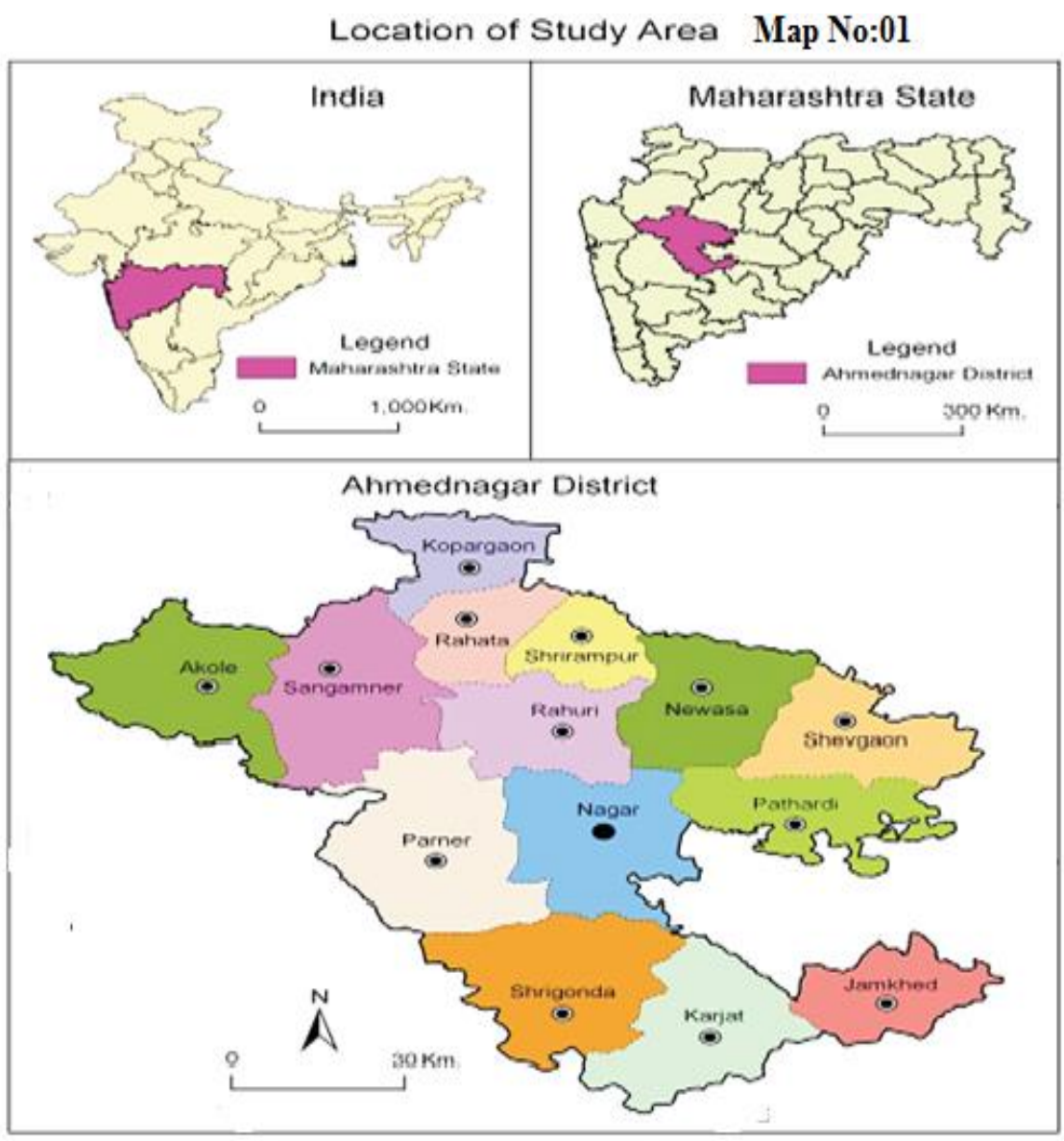


Map no 02: Rainfall Distribution in 1981

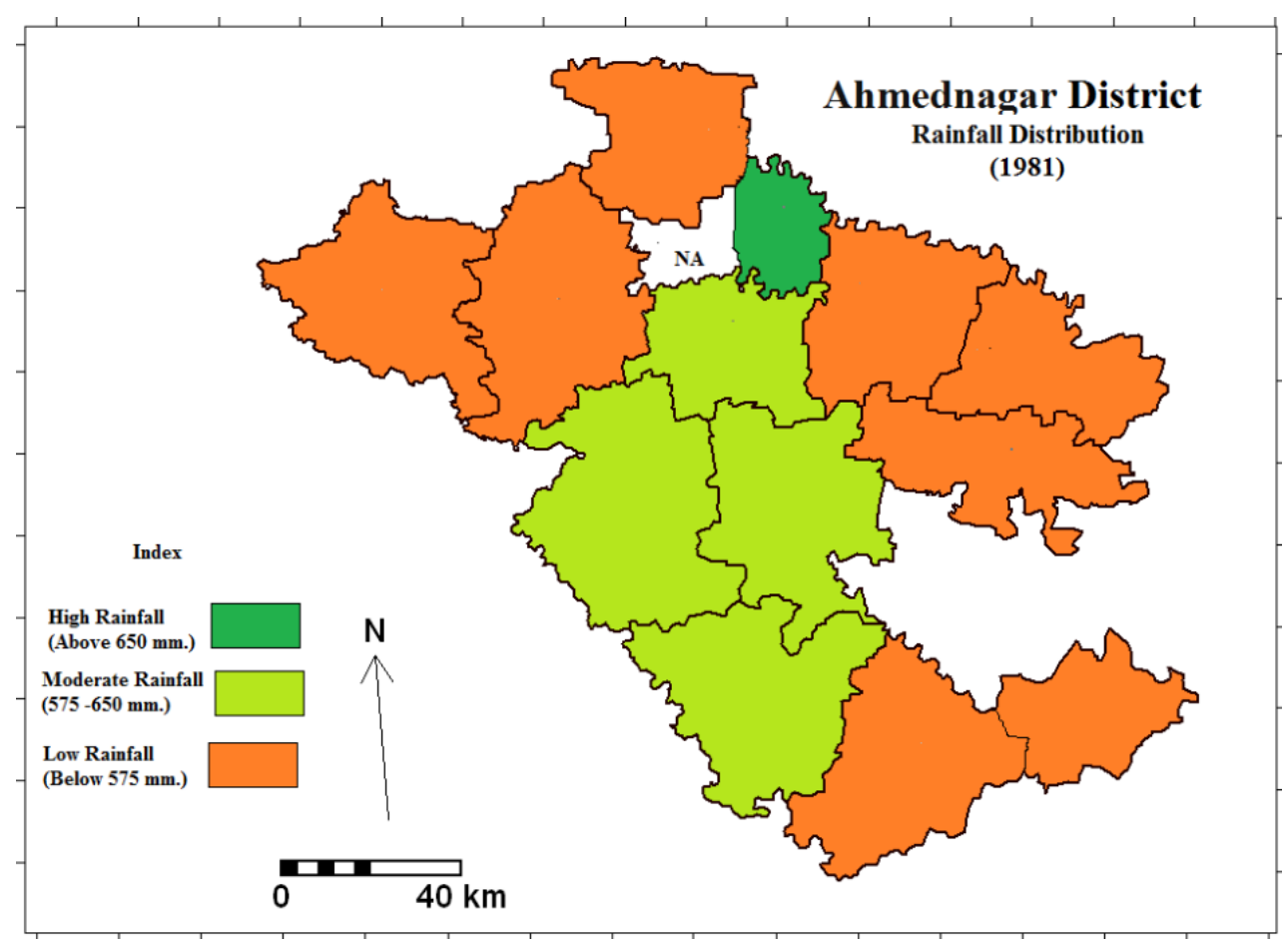

Map no 03: Rainfall Distribution in 1992

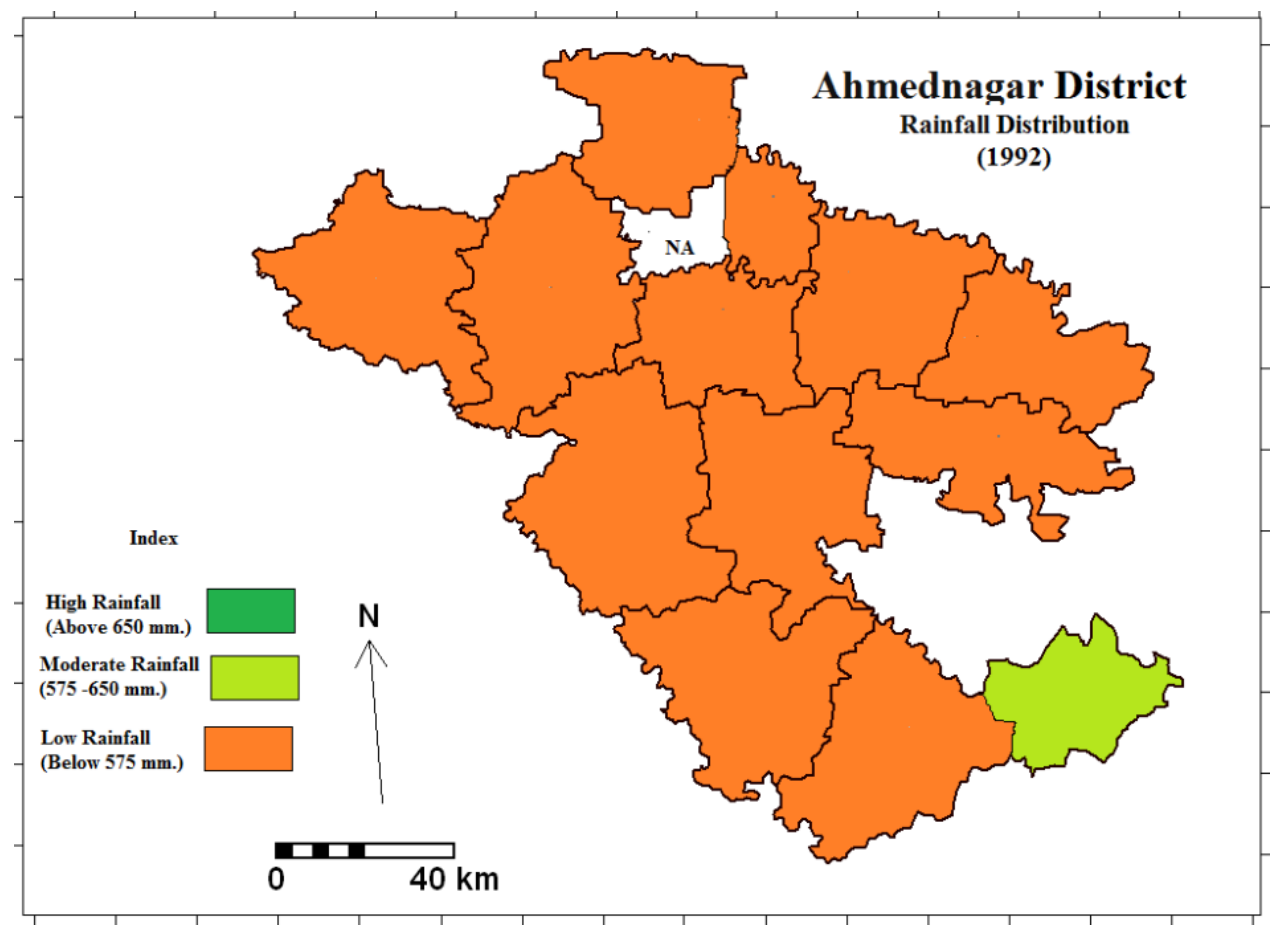


Map no 04: Rainfall Distribution in 2003

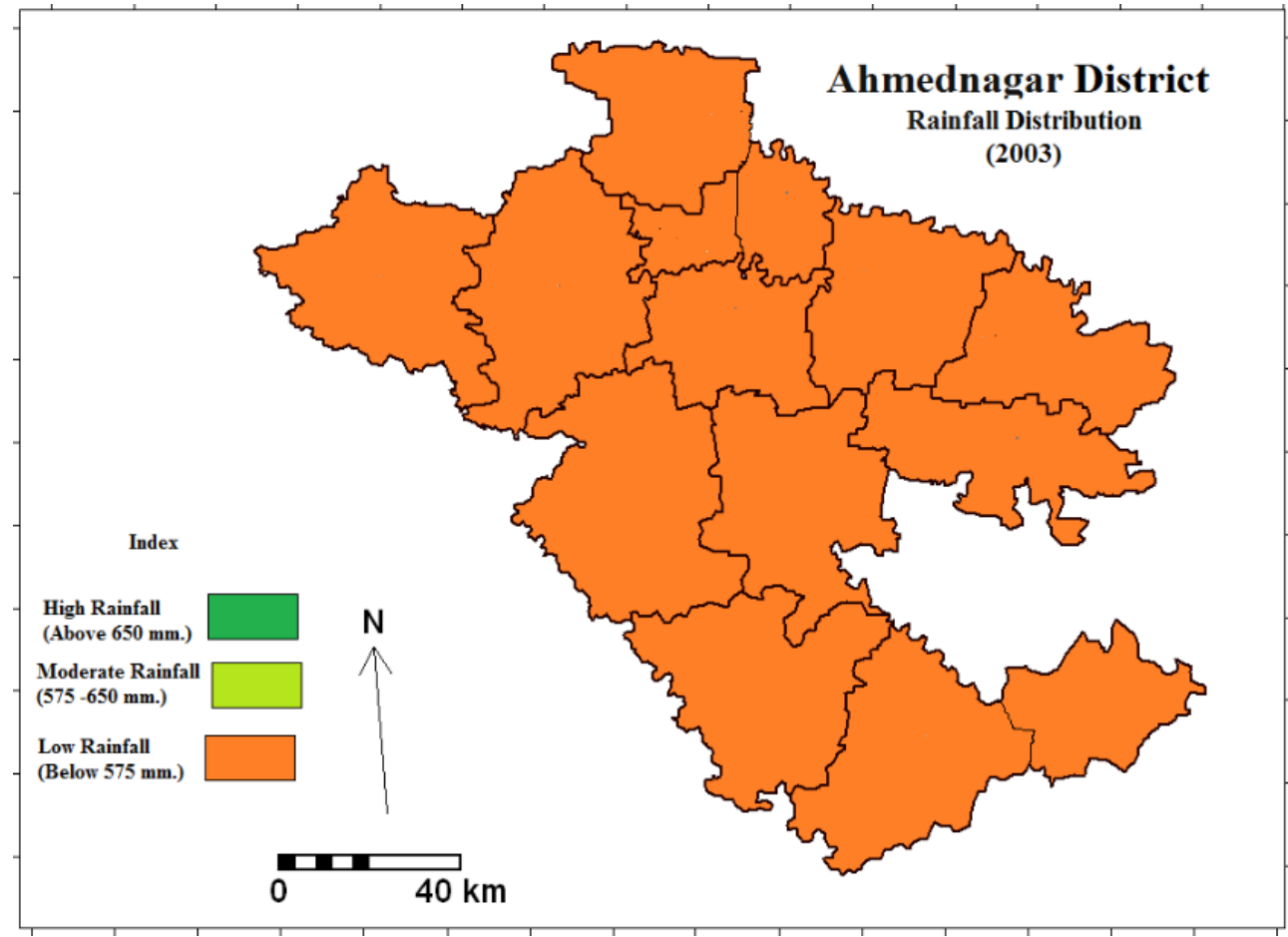

Map no 05: Rainfall Distribution in 2014

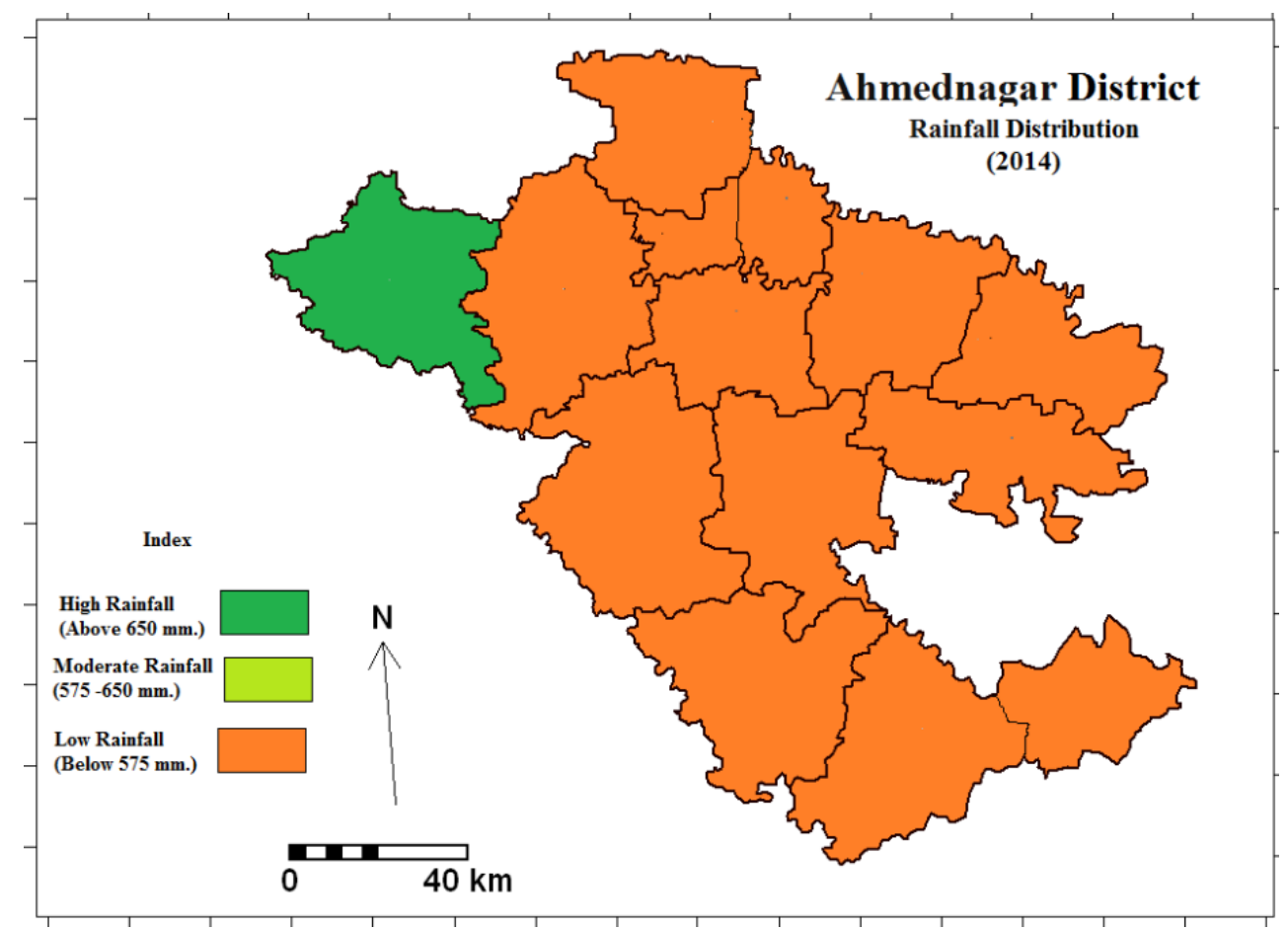


Map no 06: Rainfall Change from 1981 to 2014

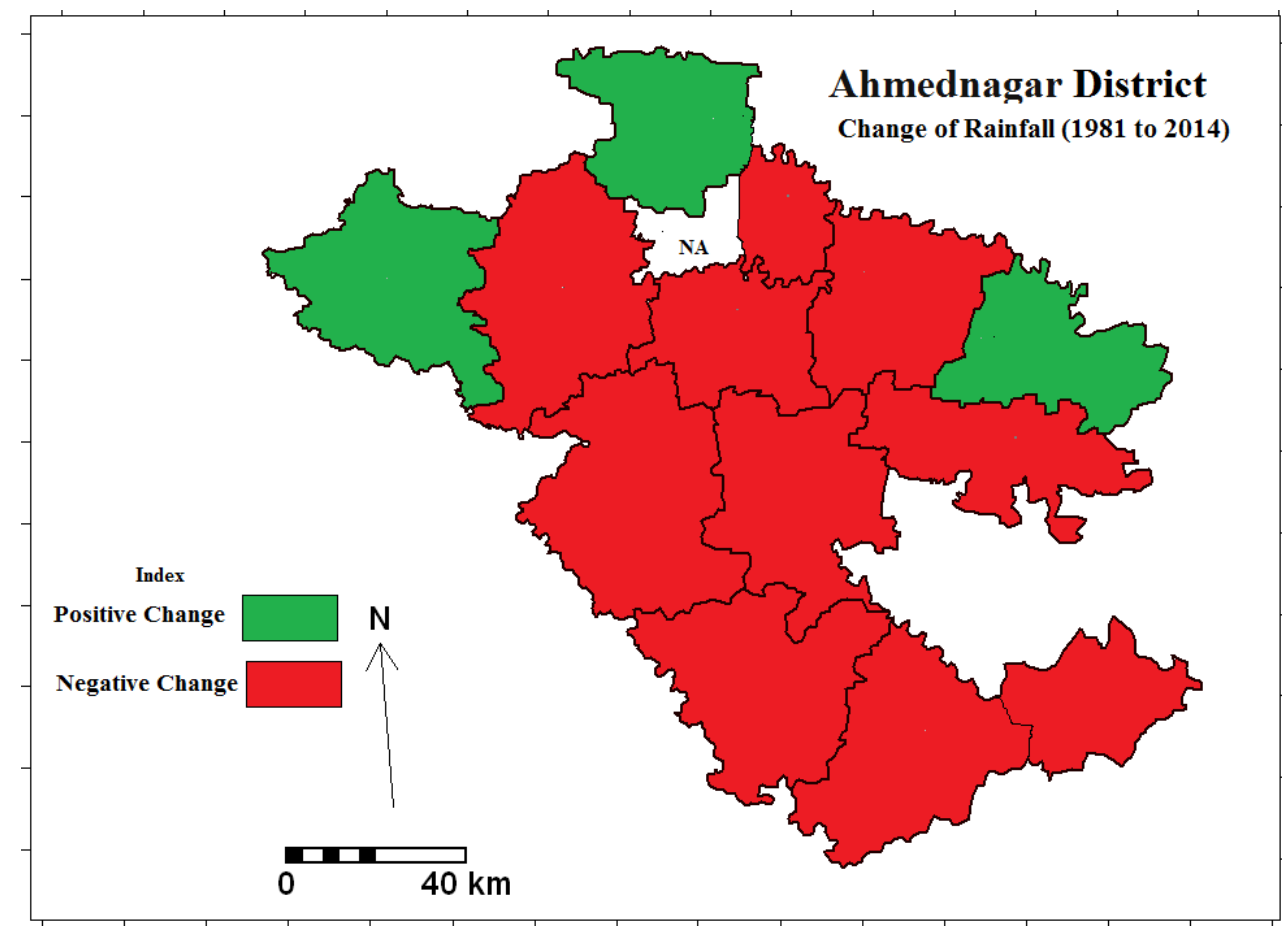

\section{IV.CONCLUSION}

The topography is the most importance factors affecting the distribution of rainfall so above average rainfall falls in Akole tehsil. With the exception of Akole tehsil in Ahmednagar district all general all tehsils have come to drought prone area. With proper use and proper planning of water in drought prone area, there will be no shortage of water. From all the above it can be seen all the tehsil of study area in general water needs to be used properly. From all the above studies it is noticed that he rainfall is decaling fall in study area.

\section{REFERENCES}

[1]. Abha Sinha et.al, (2019)Temporal Rainfall Variability and Its Correlation with Temperature over Ranchi, Jharkhand, International Journal of Engineering and Advanced Technology 9(2) 1099-1104, DOI: 10.35940/ijeat.B3429.Pp129-219

[2]. Anil A Landge et.,al. (2020)Temporal Variation of Rainfall in Ahmednagar District of Maharashtra, India. Our Heritage,68(30) Pp12850-12863

[3]. Barakade A.J. and Sule B.M. (2011) Rainfall Variability in Solapur District of Maharashtra, A Geographical Study, Review of Research , 1(2) Pp1-4.

[4]. Bisen D.K and Kudnar N.S. (2013) A Sustainable Use and Management of Water Resource of the Wainganga River Basin: - A Traditional Management Systems, figshare 
Journal

contribution.

https://doi.org/10.6084/m9.figshare.663573.v1

[5]. Bisen D.K and Kudnar N.S. (2019) Climatology, Sai Jyoti Publication, Nagpur, Pp-12-112.

[6]. Deshmukh S. Sand Pratik S. Matkar (2017) Rainfall Variability in Satara District of Maharashtra: A Case Study, International Journal for Scientific Research \& Development| 5(5) Pp1654-1656.

[7]. Gadekar Deepak Janardhan (2016) A Hybrid Land Cover Classification of Landsat-7 \& 8 (OLI) ETM+ Data for Resourceful Vegetation Mapping - Akole Thasil Dist- Ahmednagar, M.S, India, American International Journal of Research in Humanities Arts and Social Sciences, 13(3) Pp217-221.

[8]. Gadekar Deepak Janardhan (2016) Regional Disparities of Agricultural Development in Ahmednagar District, MS, India, International Journal of Research in Social Sciences, 6(8), Pp 389-403.

[9]. Gadekar Deepak Janardhan (2020) A Study of Chemical Characteristic of Pravara River in Different Sites-Ahmednagar District Maharashtra India. Our Heritage 68 (1), Pp4977-4988

[10]. Gadekar Deepak Janardhan and Mhaske P. H (2018) A Study of Rainfall Characteristics in Ahnednagar District (Ms), Shodhankan International Journal, 1 (15) Pp35-39.

[11]. Gadekar Deepak. J (2016), “A Hybrid Land Cover Classification of Landsat-7 \& 8 (OLI) ETM+ Data for Resourceful Vegetation Mapping - Akole Thasil Dist- Ahmednagar, M.S, India", American International Journal of
Research in Humanities Arts and Social Sciences, Vol. 13, Issue 3, Pp 217-221.

[12]. Jyoti P Patil et.,al. (2013)Rainfall trend analysis: A case study of Pune district in western Maharashtra region, Journal of Soil and Water Conservation 12(1), Pp35-43

[13]. Kudnar, N. S., (2015) "Linear Aspects of the Wainganga River Basin Morphometry Using Geographical Information System". Monthly Multidisciplinary Online Research Journal Review of Research, Pp Pp1-9.

[14]. Kudnar, N. S., (2015): Morphometric Analysis and Planning for Water Resource Development of the Wainganga River Basin Using Traditional \& GIS Techniques" University Grants Commission (Delhli), Pp-11-110.

[15]. Kudnar, N. S., (2017) Morphometric Analysis of the Wainganga River Basin Using Traditional \& GIS Techniques, Ph.D. Thesis R.T.M. University, Nagpur Pp-22-230.

[16]. Kudnar, N.S., (2016) Topographic Characteristics of the Wainganga River Basins Using GIS \& Remote Sensing Techniques , Multidisciplinary Research Journal, Indian Streams Research Journal, Pp-11-22.

[17]. M.E. Shejul (2020)Temporal Analysis of Human Resources Development (HRD) in Pathardi Tehsil of Ahmednagar District, Maharashtra State, India, International Journal of Scientific Research in Multidisciplinary Studies Vol.6, Issue. 8, pp.34-38

[18]. Pal S. et.,al (2015) District-wise trend analysis of rainfall pattern in last century (1901-2000) over Gangetic region in West Bengal, India, Journal of Applied and Natural Science 7 (2) ,Pp750 -757 
[19]. Ramraje Shivajirav Mane-Deshmukh, and Agastirishi Bharat Toradmal, (2019), Rainfall Trend in Drought Prone Region of Ahmednagar District of Maharashtra in India: A Geographical Study, 'Research Journey' International E- Research Journal, Special Issue 133- Agriculture and Rural Development Planning for Drought Prone Areas, Pp 78-83.

[20]. S.D Gulave (2020) Use of Landsat ETM+ Data for Delineation of Vegetation Cover Area in Akole Thasil, , International Research Journal of Engineering and Technology, Volume 7, (2) Pp57-61.

[21]. Sanjay C , P Bhasker, SL Damodare and AP Abhale (2018) Statistical analysis of seasonal rainfall variability in Nasik district by using GIS interpolation technique, Journal of Pharmacognosy and Phytochemistry 7(4) Pp 2072-2077

[22]. Shejul Meena Eknath (2020) Level of Human Resources Development - A Conceptual and Review Exposition, International Journal for Research in Applied Science \& Engineering Technology, 8 (03) , Pp 687-691. doi.org/10.22214/ijraset.2020.3130

[23]. Shejul Meena Eknath et.al, (2020) A Geographical Study of Human Resources Development in Ahmednagar District, Maharashtra, India. EPRA International Journal of Multidisciplinary Research 6 (03) Pp86-93. https://doi.org/10.36713/epra4116

[24]. Sonawane Vijay R. et.,al. (2020) Analysis of Chemical Properties of Soil under Sugarcane Crop: A Case Study of Khandala, Shrirampur, Ahmednagar District, Maharashtra State, India. Our Heritage 68(30), Pp6522-6547.
[25]. Sonawane Vijay R. et.,al.(2020) A Geographical Study of Crop Combination in Tribal Area of Nashik District, Maharashtra, India, Studies in Indian Place Names, 40 (3) Pp3915-3940.

[26]. Todkari G.U. (2012) A Geographical Study of Rainfall Variation in Solapur District of Maharashtra State, World Research Journal of Geoinformatics, 1(1) 11-13.

[27]. Vilas Vasant Patil and Agastirishi Bharat Toradmal (2020) Assessment of Rainfall Variability trend in Solapur District of Maharashtra, Aegaeum Journal 8(4) Pp234-241

[28]. Vilas Vasant Patil and Agastirishi Bharat Toradmal (2020) Identification of Groundwater Potential Prospect Zones in Semi-Arid RegionA Case Study of Karjat Tehsil, Ahmednagar District, Maharashtra, Journal of Xidian University, 14(5) Pp 814-824 https: //doi. org/10.37896/jxu14.5/085

[29]. Vilas Vasant Patil, Mr. Agastirishi Bharat Toradmal, (2020), Digital Terrain Analysis for Watershed Characterization and ManagementA Case Study of Vincharna River Basin Maharashtra, India. Journal of Information and Computational Science, 10(2). Pp 637-647 DOI:10.12733.JICS.2020.V1I2.535569.11783

\section{Cite this article as :}

Gadekar Deepak Janardhan, Soniya Sonkar, "Statistical Analysis of Seasonal Rainfall Variability and Characteristics in Ahmednagar District of Maharashtra, India", International Journal of Scientific Research in Science and Technology (IJSRST), Online ISSN : 2395-602X, Print ISSN : 23956011, Volume 7 Issue 5, pp. 125-136, SeptemberOctober 2020. Available at doi : https://doi.org/10.32628/IJSRST207525 Journal URL : http://ijsrst.com/IJSRST207525 


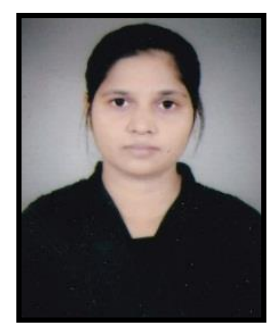

\section{Soniya Sonkar}

She pursed M.A., B.Ed., NET/ JRF, SET (Geography), Diploma in Computer Science and Ph.D. in population Studies from Department of Geography, BHU, Varanasi. I have 3 years teaching experience of Geography subject at graduation level. I have been 10 research papers in different Journals (National/International) and also different Topics.

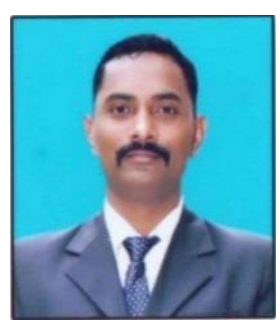

\section{Gadekar Deepak Janardhan}

He Pursed M.A., B.Ed, M.Phil and Ph.D., (SET), Geography and Post Graduate Diploma in Travel and Tourism from Savitribai Phule Pune University Pune, $\mathrm{He}$ has been the experience of teaching 06 years, in Geography subjects. He has been published more than 28 research papers in National and International level with including Thomson Reuters (UGC care listed). He main research work focuses on GIS and Remote sensing and all branch of Geography. 